\title{
Against the Grain
}

Volume 18 | Issue 1

Article 9

February 2006

\section{Robert E. Lee Memorabilia}

Alfred Warren Page Hauser

Newport News, awphjh@@att.net

Follow this and additional works at: https://docs.lib.purdue.edu/atg

Part of the Library and Information Science Commons

\section{Recommended Citation}

Hauser, Alfred Warren Page (2006) "Robert E. Lee Memorabilia," Against the Grain: Vol. 18: Iss. 1, Article 9. DOI: https://doi.org/10.7771/2380-176X.4838

This document has been made available through Purdue e-Pubs, a service of the Purdue University Libraries. Please contact epubs@purdue.edu for additional information. 


\section{Secrets of the Brain Coil}

by Dr. Debbra Ford (Psychologist, Minneapolis, Minnesota) <debbra@macconnect.com>

T make my living as a psychologist, and I know you're wondering, so let me get this cout of the way right off the bat.

I think for me, collecting might just be an effort to recover all the good stuff that my mom sold in The Big Garage Sale of '71. In fact, I've discussed it with my sister, and she's in total agreement. No Electra complex. No false memory syndrome. I just want my stuff back.

A while ago, when I was busy pursuing the dangerous and exciting life of a midwestern psychologist, I had reason to go to the American Psychological Association Website, and bumped into the usual sign-in screen. When I tried to register, it told me I was already registered, and then presented me with my secret question, so I could retrace my steps and get into the site. Not the usual "city where you were born" or "your mother's maiden name." The question I'd given myself was "name someone who was a strong influence on you in childhood."

I had absolutely no recollection of registering with this question, so I sat a minute, pondered, and gradually the answer dawned on me.

\section{Nancy Drew.}

I typed it in (case-sensitive, of course) and was instantly readmitted to the APA.
Every librarian knows that there have been a zillion print editions of the Nancy Drew Series. My first love, and first collection, is the earliest incarnation of the books; the ones with a paper dust jacket with a white spine and a blue silhouette of Nancy. They were illustrated by Russell Tandy, who gave the books their signature look from 1930 to about 1945. While the books continued to have dust jackets well into the 1960 s, the design was updated after $\# 22$. When the white spines disappear, my need to own them is gone, as mysteriously as it appeared.

I was introduced to Nancy Drew when I was seven or eight, by our baby-sitter Sue. She was five years older than me, and had a sister who was older yet. Sue gave me a few of her Nancy Drews when she became too much of a teenager to like them any more.

I love the original text of those early books, before they became "sanitized for your protection." I love the quaint language and the naive, well-intentioned political incorrectness of another time. In my secret thoughts, I still try to be plucky. I appreciate my chums, and jump in my roadster. In my work, I try to be a sleuth, and look for clues. In my head I say "slewth" and "clews," drawing out the vowels just like I did when I was nine.

I often ask women which Nancy Drew book was the best one, and they all know the name of their favorite, without having to think about it. I get lots of different answers, but I know that it was "The Mystery of the Tolling Bell."

\section{Oh, yes it was.}

Even though I've long since procured an example of each white-spine book, I still have the habit of looking for them whenever I'm in a used book store. They're very easy to spot, there in the children's book section amongst the Hardy Boys and the Bobsey Twins. Book dealers know they have to be displayed in numerical order, of course, and the best place in the section is always where you'll find the Nancy Drew books.

I'll never sell my Nancy Drews. I assume when I'm dead and gone, the whole collection will be cared for in perpetuity by my much younger niece. She is, of course, a book collector.

And a librarian..... heh heh.

\section{Robert $\mathbb{E}_{\text {。 }}$ Lee Memorabilia}

\section{by Alfred Warren Page Hauser (Retired Jeweler, Newport News, Virginia) <awphjfh@att.net>}

$\mathrm{M}$ y first wife gave me a set of Lee's Lieutenants as a first anniversary gift on November 11, 1945. I also had the four-volume set of Douglas Southall Freeman's biography of Robert E. Lee, but I had never read any of them until the past couple of years. I think those books started my collection. Over 30 years ago, I received a print of the famous The Last Meeting of Generals Robert E. Lee and Stonewall Jackson on the evening of the day before the Battle of Chancellorsville, May 1, 1863, by JULIO of New Orleans. That got me started with pictures of Lee. I have several of Lee and a big picture of Lee and his generals. When my wife and I made a trip to Stratford Hall, Lee's birthplace, we picked up a print of Stratford and a map showing his travels, genealogy, and important events in his life. When we had all of them put up in a room, we decided to call it "the Lee Room." My friend Dewey Stinson got me more involved with Confederate history, persuading me to join the Sons of Confederate Veterans group, where we learn about other members' histories, study battles, and review books.

I continue to collect books about Lee and the Civil War because Robert E. Lee was, and still is, my hero. He was a good Chris- tian man, a fine example for a youth to emulate. He never spoke of the Yankees as enemies, but as "those people." And he definitely did not fight to preserve slavery. I even named my son Lee after Robert E. Lee. My wife and I buy books that we want to read. She reads aloud to me every night. That way we don't have to fight over the books, and also we can discuss them as we read. It works out well.

Reading about the War helps me to understand my ancestors. My great-grandfather Robert Page fought in the War in the cavalry under Jeb Stuart. Two of his brothers did, too. Carter

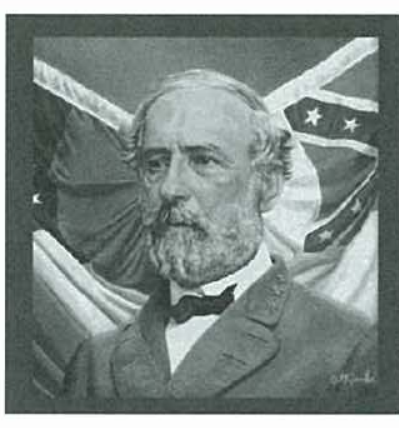

he died of poor health before the war ended. So you see, I have a personal interest in the war. I would love to find a photo of these brothers. I do have a photo of my great-grandmother, Anna H. Page, who lived next door to me when I was a small boy. I was too young to ask her questions about her husband, but I wish I could have.

My wife's great-grandfather was in the War... on the other side. He enlisted at a very young age as a drummer boy. But he didn't write anything about the War. We are at a dead end finding out about him, though we do have a photo of him sitting on the porch of a house in Richmond.

My Lee-related collecPage joined under General Pegram, was captured and exchanged and joined the cavalry under General Mosby. When his horse was shot out from under him, he was wounded and sent to the Old Capitol Prison at Washington. He was again exchanged and enlisted a third time, this time with the Richmond Howitzers. So he served in all three branches of the service: Infantry, Cavalry, and Artillery. John Page was in the Richmond Howitzers also, though tions are important to me and my family, not necessarily significant cultural records. My grandson and one granddaughter are interested in hearing about family stories, but I doubt anyone else is. I am hoping my grandchildren will pass it along to their children, and so on. My wife and I are trying to get these stories together and written down so we can pass them along. If they're not written, they're lost. 